\title{
Design and Calculation of Multi-angel and Stepping Transmission of Sucker Rod Forging
}

Liu Yimin ${ }^{1,2}$, Wang Jie ${ }^{2}$

${ }^{1}$ School of Manufacturing Science \& Engineering, Sichuan University. No.24, Section 1, 1st Ring Road(South), Chengdu, China. E-mail: wangjie@scu.edu.cn

${ }^{2}$ The Institute of Exploration Technology of CAGS. No.1, Section 2, 1st Ring Road(North), Chengdu, China. E-mail: 153973418@qq.com

The paper puts forward structure design and parameter analysis of the multi-angle and stepping transmission device, and this paper focuses on design and analysis of the multi-angle steering parts in the device. According to mathematical calculation and simulation analysis, the parts size of steering component is simulated and designed by the double cam-linkage mechanism. Though the design of these critical components of the steering device, the rods can be rotated in the specified angle $\left(45^{\circ}\right.$ and $\left.90^{\circ}\right)$ by their relative motion without any external force, and the steering device is simulated by SolidWorks Motion. The results show that the multi-angle and stepping transmission device realizes the upset forging process requirements, improves the mechanization level of the sucker rod forging. The device will be used for the rod head machining operation in narrow space in automatic production line, and it also can be extended to other cylindrical rod's multi-angle and multi-position automatic machining operation.

Keywords: Multi-angle, Stepping Transmission, SolidWorks Motion, sucker rod forging.

\section{Acknowledgement}

This work is supported by the Natural Science and Technology Foundation of Sichuan Province under Grant No. 11H048, and CGS of P.R.China geological survey project No.1212011220169, No.12120113011100

\section{References}

[1] LI KUN, GAO XIANWEN, TIAN ZHONGDA. (2013). Using the curve moment and the PSO-SVM method to diagnose downhole conditions of a sucker rod pumping unit, In: Petroleum Science, Vol. 54, No. 1, pp. 5 - 28. China.

[2] WU ZEZHONG, ZHONG YONGHAI, MENG ZHONGLIANG. (2008). The status and trend of sucker rod develpment in China, In: China Petroleum Machinery, Vol. 36 , No.2, pp. 63 - 66. China.

[3] B.-A. BEHRENS. (2008). Finite Element Analysis of Die Wear in Tot Forging Processes, In: CIRP Annals-Manufacturing Technology, Vol. 57, No. 1, pp. 305 - 308. USA.

[4] ZHENG WENWEI, WU KEJIAN. (2005). Theory of Machines and Mechanisms, pp. 12 - 17. Higher Education Press, Beijing.

[5] CHEN CHAOXIANG, HU QIDENG. (2006). SolidWorks Motion Simulation Tutorial, pp. 22 - 24. China Machine Press, Beijing.

[6] GE HAO, GAO FENG. (2012). Type Design for Heavy-payload Forging Manipulators, In: Chinese Journal of Mechanical Engineering, Vol. 65, No. 2, pp. 197 - 205. China.

[7] WANG SHUANG, YIN GUOFU, LUO ZHONGXIAN. (2007). Motion analysis and simulation of planar cam mechanism, Machinery Design \& Manufacture, Vol. 55, No. 10, pp. 42 - 43. China.

[8] JIAN LIANGPENG. (2010). Identification and Solution to Bottleneck of Supply Chain Based on Flexsim, In: Proceedings of the 2010 International Conference on Intelligent Computation Technology and Automation, pp. 461-465. Japan.

[9] ZHANG CHENGGUANG, ZHANG YONG, ZHANG FEIHU. (2014). Mechanism of ultrasonic-pulse electrochemical compound machining based on particles, In: Journal of Central South University, Vol. 21, No. 1, pp. 151-159. China.

[10] ZHOU XINJIAN, XU XIANGBIN, ZHU WEI. (2011). Simulation and optimization in production logistics based on M-plant platform, In: IFIP Advances in Information and Communication Technology, Vol. 347, No. 4, pp. 486-493. USA.

[11] X. J. LIU, H.C. WANG, D.W. LI. (2007). Study on design techniques of a long life got forging die with multi-materials, In: Acta Metallurgica Sinica (English Letters), Vol. 91, No. 2, pp. 83-96. China.

Paper number: M2014119

Copyright (C) 2014. Published by Manufacturing Technology. All rights reserved. 